doi: 10.32620/oikit.2021.94.03

УДК 629.7.014-519:004

О. Г. Гребеніков, О. С. Калоша

\title{
Метод створення навчального БПЛА літакового типу за допомогою 3D-друку
}

\author{
Національний аерокосмічний університет ім. М. Є. Жуковського \\ "Харківський авіаційний інститут»
}

\begin{abstract}
Запропоновано концепцію спеціалізованого навчального безпілотного літального апарату (БПЛА) літакового типу для операторів безпілотних літальних апаратів. Висвітлено навчальні можливості відносно різних напрямів підготовки операторів. Розроблено метод виготовлення навчального БПЛА літакового типу з урахуванням аеродинамічних та вагових характеристик. В основі розробленої методики використовується отримання деталей літака за допомогою 3D-принтера, якого модифріковано з урахуванням вимог до малорозмірних апаратів літакового типу. Така методика включає також процес вибору найвигіднішого поєднання матеріалів для створення літака невеликого розміру. Наведено таблиці з вихідними даними існуючих БПЛА.

Запропоновано льотно-технічні характеристики, аеродинамічні схеми і тип двигуна, які найбільш відповідають безпілотним літальним апаратам такого класу. На основі цих даних було побудовано модель-прототип, прийнято методику проектування БПЛА з урахуванням вибору параметрів силової установки. Наведено демонстраційний приклад вибору основних параметрів навчального БПЛА з урахуванням конкретних вимог. Подано отримані основні технічні характеристики БПЛА. На основі розрахункових даних розроблено тривимірну геометричну модель БПЛА та виготовлено льотний зразок. Проведено серію випробувальних польотів льотного зразка, який було випробувано при складних погодних умовах, коли сила вітру дорівнювала близько 12 м/с. Розглянуто шляхи використання описаної методики розроблення навчально-дослідних БПЛА, а також багато інших чинників, що впливають на 3D-друк без виявлення десеектів та проблем.
\end{abstract}

Ключові слова: навчальний БПЛА; літак; злітна маса; вибір параметрів; проектування; аеродинаміка; 3D-друк; льотний зразок; випробування.

Розвиток сучасних технологій та підвищення їх доступності обумовили розширення можливостей використання безпілотних літальних апаратів у різних сорерах людської діяльності.

Впровадження БПЛА в галузі господарської діяльності спричинило появу нової професії - зовнішніх пілотів чи пілотів-операторів БПЛА. При цьому потреба в таких фрахівцях настільки збільшилася, що в останні роки в Україні відкриваються цілі напрями підготовки пілотів-операторів на базі існуючих комерційних та державних навчальних закладів.

Слід зазначити, що масове навчання здобуття цієї профресії потребує наявності істотної матеріальної бази в навчальних організаціях, що визначається переважно існуванням БПЛА різних типів, на яких набувають навичок безпосереднього керування та самостійного розроблення польотних завдань для автопілота під час виконання польоту в автоматичному режимі.

Практичне вивчення стадій життєвого циклу літального апарата підносить навчальний процес на якісно інший рівень: з'являється зв'язок отриманих теоретичних знань з практичною реальністю, відбувається матеріальне сприйняття законів природи, підвищується відповідальність за прийняття технічних рішень, починає накопичуватися професійний досвід практичної діяльності на промисловому підприємстві. Це допомагає майбутнім інженерам-аеродинамікам вивчи- 
ти механіку газу в теорії та на практиці: контрольно-вимірювальна апаратура на борту БПЛА дозволить отримувати характеристики динаміки польоту. Студентитехнологи зможуть власноруч виготовляти планер БПЛА, зображений на рис. 1, освоюючи на практиці сучасні технології виробництва літакових конструкцій, а також 3D-друку. I, нарешті, пілоти-оператори застосовують літальний апарат для набуття початкових навичок пілотування та обслуговування апарата після проходження підготовки з використанням авіасимулятора.

Реалізація такого комплексного підходу під час підготовки майбутніх кадрів авіаційної промисловості в навчальному закладу є можливою із застосуванням простих у технічному плані навчальних БПЛА з доступних недорогих матеріалів, обладнаних сучасною електронікою, малих габаритів та маси.

На сьогодні немає певних норм льотної придатності, які б регламентували вимоги до навчальних БПЛА, що враховуються під час проектування. Відомі методики проектування не орієнтовані на літальні апарати такого малого розміру та надмалих швидкостей польоту. Водночас такий БПЛА належить до літальних апаратів, при проектуванні яких враховують всі основні фрізичні принципи, включаючи закони аеродинаміки, динаміки польоту, механіки твердих тіл тощо. На зміну послідовному підходу приходять методики комплексного, одночасного впливу ключових показників ефективності ЛА на його технічний вигляд загалом, в яких використовують математичні моделі з різних предметних дисциплін та методи багатодисциплінарної оптимізації з можливістю формалізації, алгоритмізації та автоматизації розрахунків.

Метою цієї роботи є вибір основних параметрів навчального БПЛА з одночасним врахуванням аеродинамічних, вагових та енергетичних характеристик, а також декілька спеціальних вимог.

\section{Вимоги до навчальних БПЛА літакового типу}

Розглянемо вимоги до навчальних БПЛА. Такий апарат повинен мати властивість «прощати» помилки пілотування, які неминуче можуть виникнути під час навчання майбутніх пілотів. Таким чином, такий апарат (див. рис. 1) повинен мати необхідний запас поздовжньої, шляхової та поперечної статичної стійкості, а також необхідні характеристики бічної стійкості в балансі з об'єктивними характеристиками.
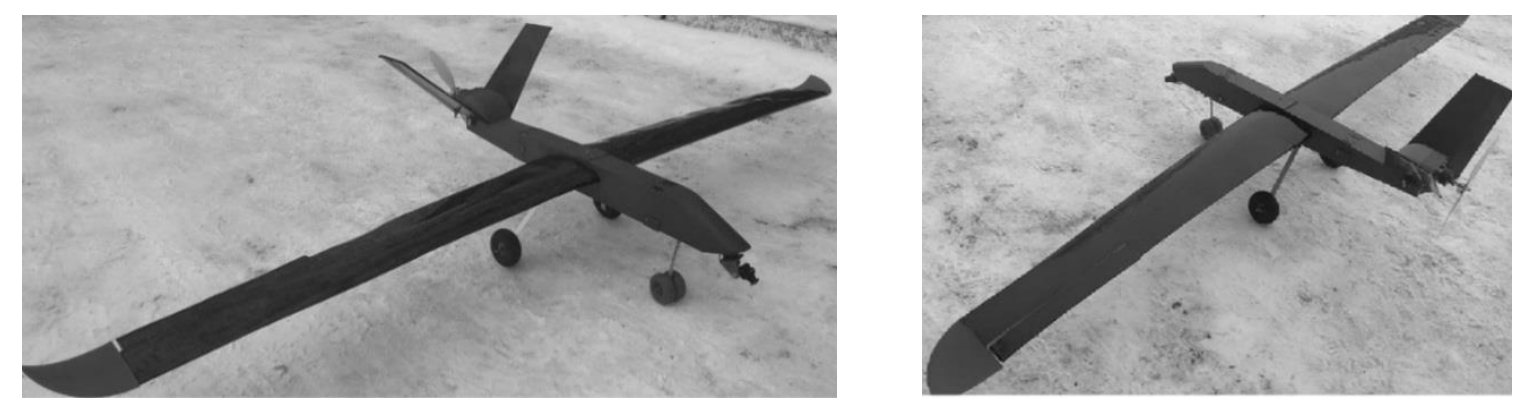

Рис.1. Створений літаючий зразок

Значна тривалість польоту навчального апарата не є обов'язковою, цю обставину можна використовувати з метою зниження злітної маси та питомого навантаження на крило.

За результатами збору та оброблення статистичних даних міні БПЛА лі- 
такового типу було сфрормовано табл. 1, в якій вказано назву, довжину, розмах крила, масу, максимальну швидкість, крейсерську швидкість, тривалість польоту, дальність польоту, максимальну висоту польоту. На рис. 2 зображено БПЛА, які були вибрані для отримання статистичних даних.

Таблиця 1

Статистичні дані БПЛА щодо льотних параметрів

\begin{tabular}{|c|c|c|c|c|c|c|c|c|c|}
\hline $\begin{array}{l}\mathbb{N} \\
\stackrel{\infty}{0} \\
\mathbb{N} \\
\text { I }\end{array}$ & 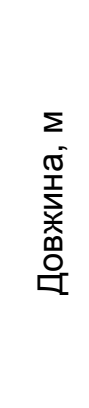 & 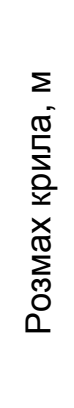 & 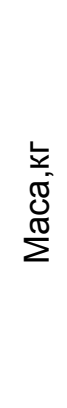 & 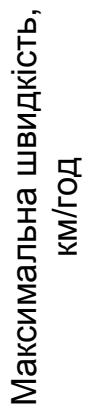 & 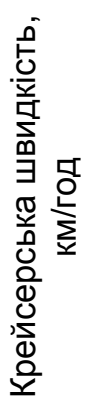 & 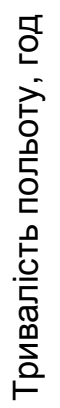 & 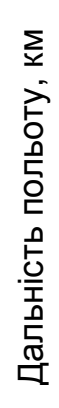 & 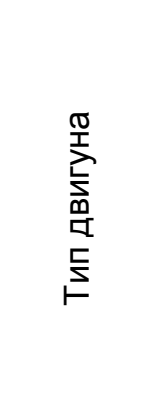 & 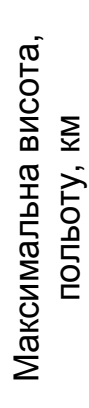 \\
\hline SMG220 & 1,2 & 2,2 & 3,5 & 90 & 50 & 1 & 70 & Електро & 4,1 \\
\hline KC2000 & 1,08 & 2 & 2 & 140 & 100 & 3 & 60 & Електро & 0,5 \\
\hline AL-4 & 1,4 & 2 & 4,2 & 100 & 55 & 1 & 90 & Електро & 3 \\
\hline LANKASTER-5 & 1,4 & 1,5 & 3,5 & 80 & 57 & 1 & 15 & Електро & 2,5 \\
\hline
\end{tabular}

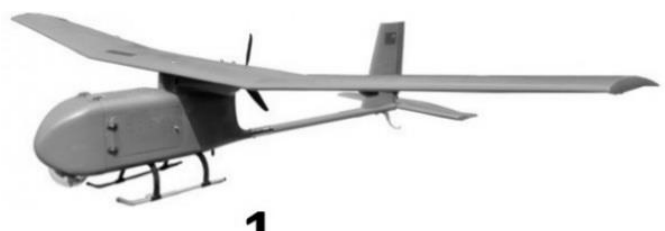

1

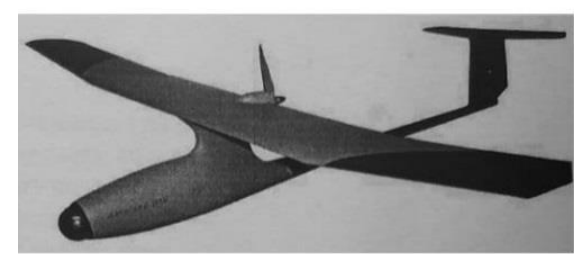

3
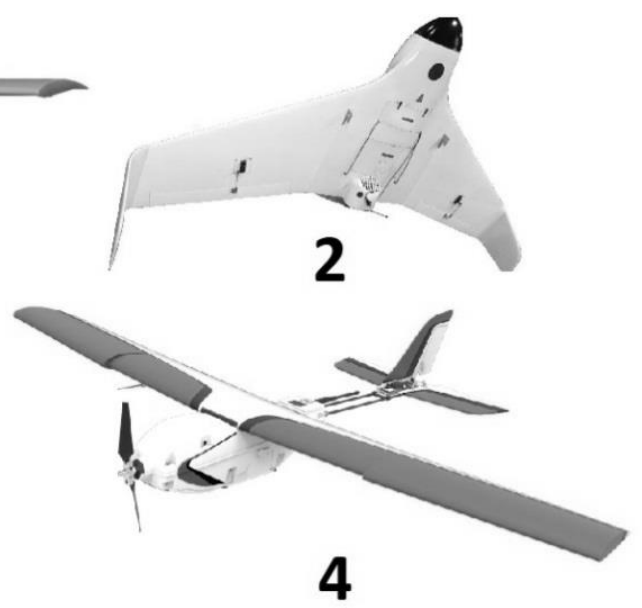

Рис. 2. Загальний вигляд БПЛА:

1 - SMG-220, 2 - KC-2000, 3 - AL-4, 4 - LANKASTER-5

Для отримання початкових навичок пілотування слід вибрати найпростіші конструкції, який виготовляють з доступних та недорогих матеріалів без використання складного спеціалізованого обладнання, що полегшує та прискорює процес виготовлення літака та його ремонт у разі можливих несправностей. 3 цих міркувань доцільним $є$ оснащення БПЛА електричним двигуном. Для зручності транспортування, експлуатації, швидкого розгортання та складання слід виконувати літак найкомпактніших габаритів зі зручним членуванням конструкції. 
Відомо, що врахування властивостей кожної функціональної частини ЛА потребує певних масових витрат під час виробництва ЛА.

Сукупність мас всіх частин літака визначає його злітну масу $m_{0}$, що характеризує і свідчить про можливість польоту,а також є одним з основних параметрів у концептуальному проектуванні.

Обчислюють злітну масу за допомогою рівняння існування:

$$
m_{0}=\sum_{i} m_{i} / \sum_{i}\left(1-\bar{m}_{k}\right)
$$

де індекс підсумовування $i$ належить до заздалегідь відомих мас частин літака, що записують у чисельнику дробу, індекс $k$ - до відносних мас частин літака у знаменнику, величина абсолютної маси яких підлягає визначенню.

Використання рівняння існування (1) у класичній формі для малорозмірних літальних апаратів може бути незручним через те, що деякі маси мало залежать від розмірів такого БПЛА та його злітної маси. Крім того, одні категорії мас доцільно виділити в окремі доданки, інші - об'єднати в один. У такому разі рівняння (1) доцільно переписати у такому вигляді:

$$
m_{0}=\frac{m_{\text {об.кер }}+m_{\text {об.авт.кер }}+m_{\text {ел.м }}+m_{p}}{1-\left(\bar{m}_{\text {ак.б }}+\bar{m}_{\partial в}+\bar{m}_{n .2}+\bar{m}_{\kappa}\right)},
$$

де $m_{\text {об.кер }}=m_{c . n}+m_{p . n}+m_{p . o}-$ маса обладнання керування, яка може бути відома раніше, $m_{c . n}$ - маса сервопривіду, $m_{p . n}$ - маса приймача радіосигналу, $m_{p . o}$ - маса регулятора обертів двигуна, $m_{\text {ел.м }}$ - маса електромережі, $m_{p}$ - резерв, $m_{\text {об.авт.кер }}$ - маса обладнання автоматичного керування, $\bar{m}_{a \kappa . б}$ - відносна маса акумуляторної батареї, $\bar{m}_{\partial в}$ - відносна маса двигуна силової установки, $\bar{m}_{n .2}-$ відносна маса повітряного гвинта , $\bar{m}_{\kappa}-$ відносна маса конструкції планера.

Відносна маса акумуляторів залежить від тривалості польоту:

$$
\bar{m}_{a \kappa . \sigma}=\frac{k_{a \kappa . \sigma} \gamma_{a \kappa . \sigma} \bar{N} T}{\eta_{\partial \varepsilon}}
$$

де $\gamma_{а к . б}$ - питома маса акумулятора, кг/Вт·год; $N$ - потрібна енергоозброєність літака, Вт/кг; $T$ - потрібний час польоту, год; $\eta_{д в}-$ коефіцієнт корисної дії двигуна; $k_{a \kappa . б}$ - коефіцієнт, що враховує збільшення маси акумулятора за рахунок маси корпусу, проводів та роз'ємів.

Відносна маса двигуна:

$$
\bar{m}_{\partial \theta}=k_{\partial \theta} \gamma_{\partial \theta} \bar{N}
$$

де $\gamma_{\partial в}-$ питома маса двигуна, кг/Вт; $k_{\partial в}-$ коефіцієнт, що враховує збільшення маси двигуна за рахунок системи кріплення, проводів та кріпильних елементів.

Потрібна енергоозброєність визначається із запасом на набір висоти за даним градієнтом:

$$
\bar{N}=\left[\frac{1}{K_{\text {наб }}}+\operatorname{tg} \theta\right] \frac{V_{g}}{\eta_{n .2}}
$$

де $K_{\text {наб }}$ - аеродинамічна якість у наборі висоти із заданим кутом нахилу траєк- 
торії; $\theta$ - заданий кут нахилу траєкторії при набиранні висоти; $V$ - швидкість польоту, м/с; $g$ - прискорення вільного падіння; $\eta_{n .2}-$ ККД повітряного гвинта.

Відносну масу повітряного гвинта визначають з розрахунку середньої маси одного метра лопаті, помноженої на діаметр гвинта та співвіднесеної до злітної маси літака:

$$
\bar{m}_{n .2}=\frac{k_{n .2} D_{n .2}}{m_{0}},
$$

де $D_{n .2}-$ діаметр повітряного гвинта, м; $k_{n .2}$ - погона маса повітряного гвинта, $\mathrm{K} \Gamma / \mathrm{M}$.

Маса конструкції планера навчального БПЛА, на відміну від більших пілотованих ЛА, через його малу розмірність і низьку інтенсивність навантаження основних силових елементів, часто визначається технологією виготовлення та експлуатаційними вимогами, а не силовою роботою її елементів. Таким чином, відносна маса конструкції переважно залежить від абсолютних розмірів БПЛА.

Масу силових елементів (лонжеронів, шпангоутів), що виготовляють із міцних матеріалів, визначають за умов жорсткості. Всі елементи конструкції, параметри яких вибрані з міркувань технології та жорсткості, підлягають перевіреному розрахунку на міцність. У зв'язку із залежністю деяких мас окремих частин літака від злітної маси і, навпаки, її розраховують повторно до досягнення збігу мас.

\section{Демонстрація літаючого прототипу}

Згідно з вимогами до навчальних БПЛА прийнято такі концептуальні рішення: БПЛА літакового типу виконують за нормальною аеродинамічною схемою з одним електричним двигуном і гвинтом, що штовхає, трьохопорним шасі 3 носовою опорою. Крило (рис. 3) обладнане механізацією задньої кромки у вигляді елерону. Профріль крила помірної товщини має опукло-плоску форму з метою спрощення виготовлення крила. Передбачено можливість польоту як у ручному, так і автоматичному режимах. Основний матеріал конструкції - PLAпластик, алюміній в силових елементах, що працюють на розтягуваннястиснення, пінополістирол - в силових елементах, що працюють на зсув, який використовують як заповнювач.

Головною метою виробництва навчальних БПЛА $є$ максимальна економічна ефрективність.

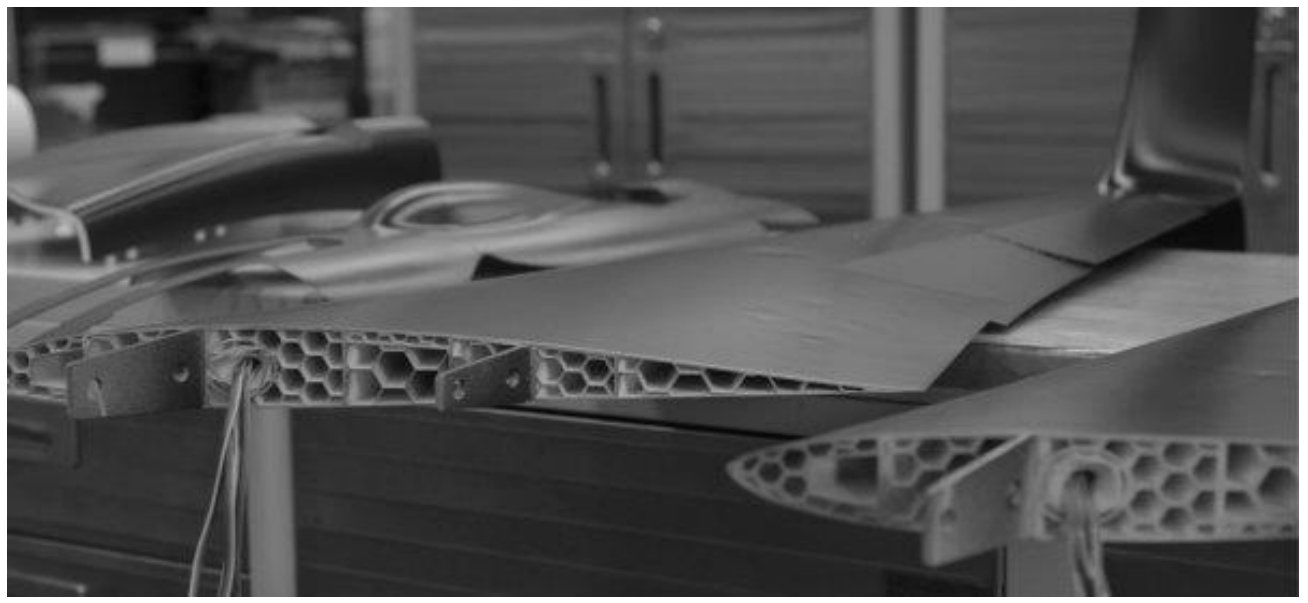

Рис. 3. Крило в розрізі 
3D-друк може суттєво допомогти цьому, відкриваючи нові межі для всіх видів проектування. Адже легкі БПЛА витрачають менше пального або електроенергії, що дає можливість знизити витрати на експлуатацію, а також зменшити негативний вплив на навколишнє середовище. Крім цього, з використанням лише точної кількості матеріалу, необхідного для виготовлення БПЛА, очікується зниження його вартості за рахунок усунення відходів та скорочення витрат на утилізацію.

\section{Оптимальні налаштування програми Cura для 3D-друку різних агрегатів БПЛА}

Шляхом проб та помилок можна поступово налаштувати програму Cura для 3D-друку із PLA-пластику. Нижче наведено рекомендації, які можуть бути корисними для застосування PLA-пластику на 3D-принтері, а також програми Cura для слайсингу та підготовки режимів 3D-друку. Розглянуто розширену підтримку та налаштування заповнення, а також багато інших фракторів, що впливають на 3D-друк без створення дефектів та проблем. Вказані налаштування призначено для Cura та протестовано на 3D-принтері. Ці налаштування було успішно використано на принтерах Anycubic mega zero. Умови навколишнього середовища та матеріалу у різних виробників значно впливають на вказані налаштування.

\section{Налаштування якості 3D-друку}

Висота шару 3D-друку залежить від розміру сопла 3D-принтера, а також від якості. 3D-принтер із соплом, що дорівнює 0,6 мм, може забезпечити товщину шару до 0,4 мм, а деталь із висотою шару 0,1 мм займе вдвічі більше часу на виготовлення, ніж із соплом 0,2 мм, тому ці чинники важливо враховувати.

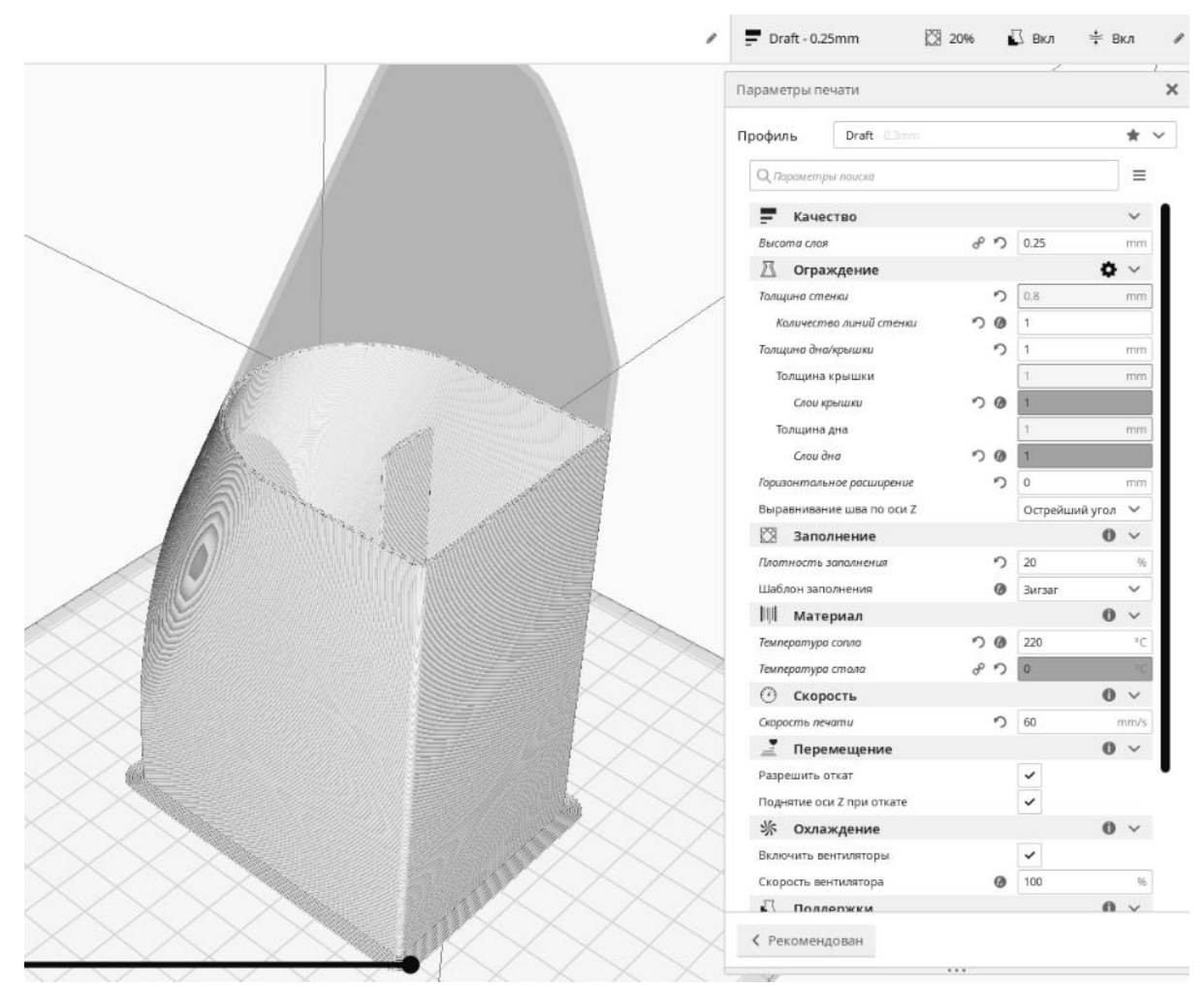

Рис. 4. Скриншот налаштування якості 3D-друку 
Стандартні налаштування якості 3D-друку (рис. 4): висота шару 0,25 мм. Налаштування ретракту для PLA: Minimum Travel: $1.5 \mathrm{~mm}$. Enable Combing: All. Minimal Extrusion Before Retracting: 0.005 mm. Z "Z Нор" при втягуванні встановлено на 0,1 мм, тому тонкі ділянки 3D-моделей будуть пошкоджені з меншою ймовірністю. На рис. 5 - рис. 8 показано приклади 3D-друку. У меню Quality у розділі Advanced потрібно збільшити початкову ширину лінії до 115 \%. Це допомагає покращити адгезію з робочою поверхнею столу без погіршення якості 3Dдруку.

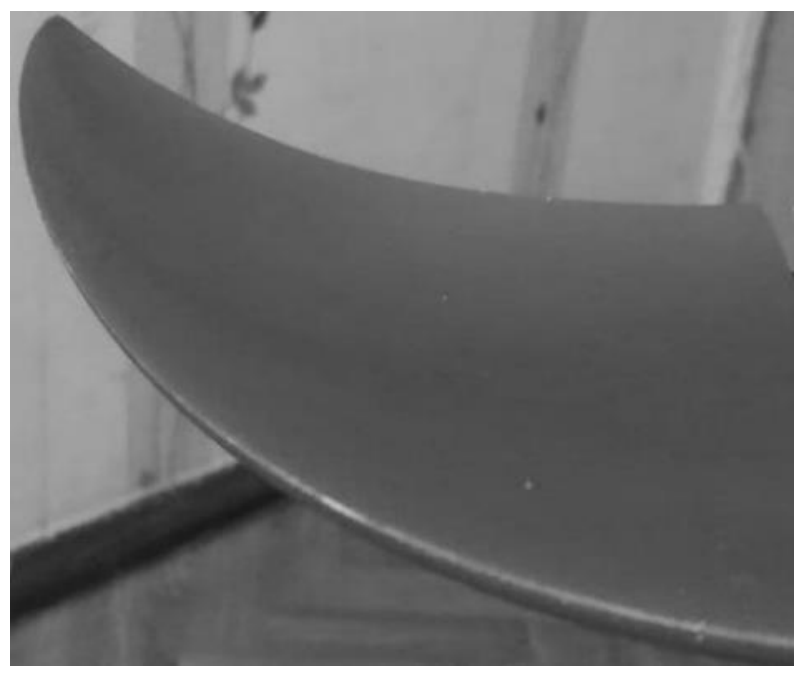

Рис. 5. Правий вінглет

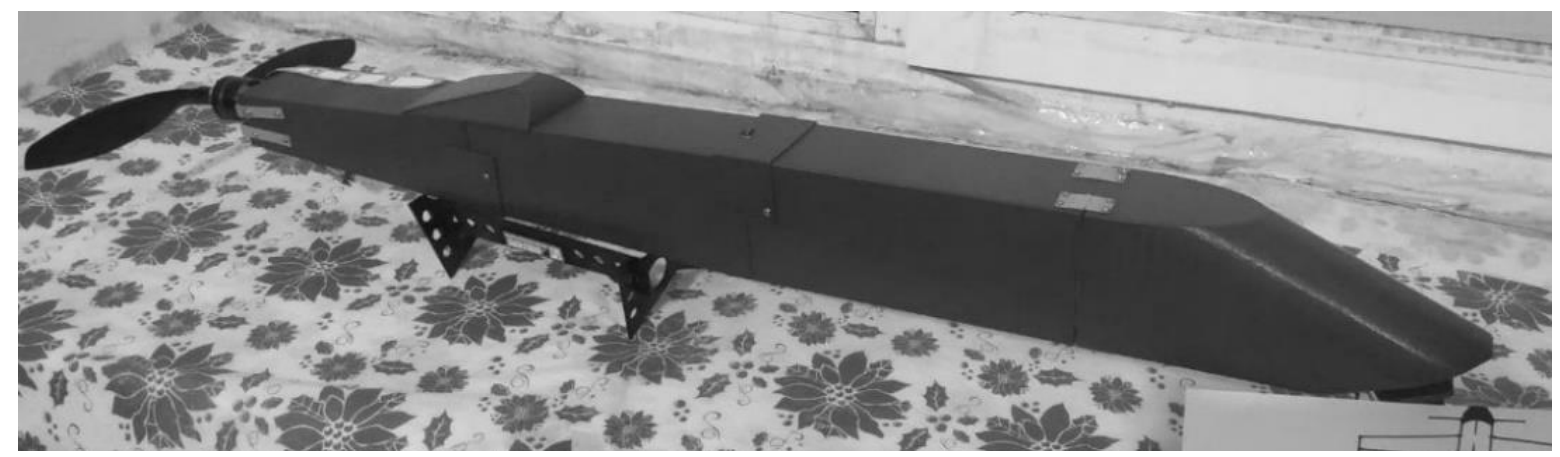

Рис. 6. Фюзеляж на стадії збирання

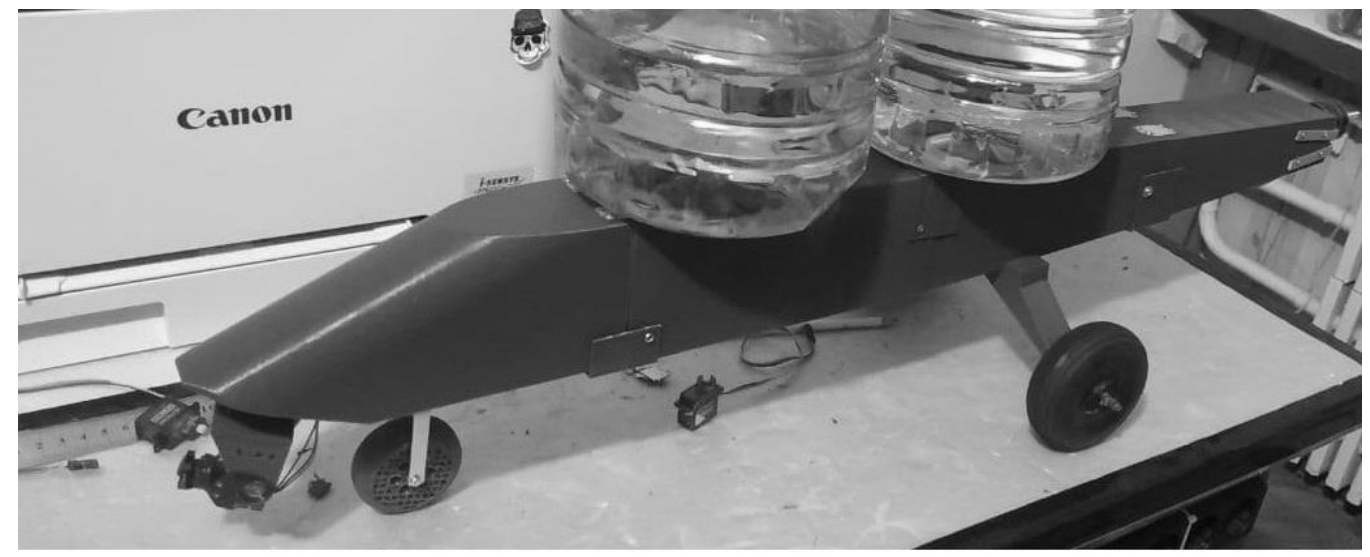

Рис. 7. Тест на міцність 


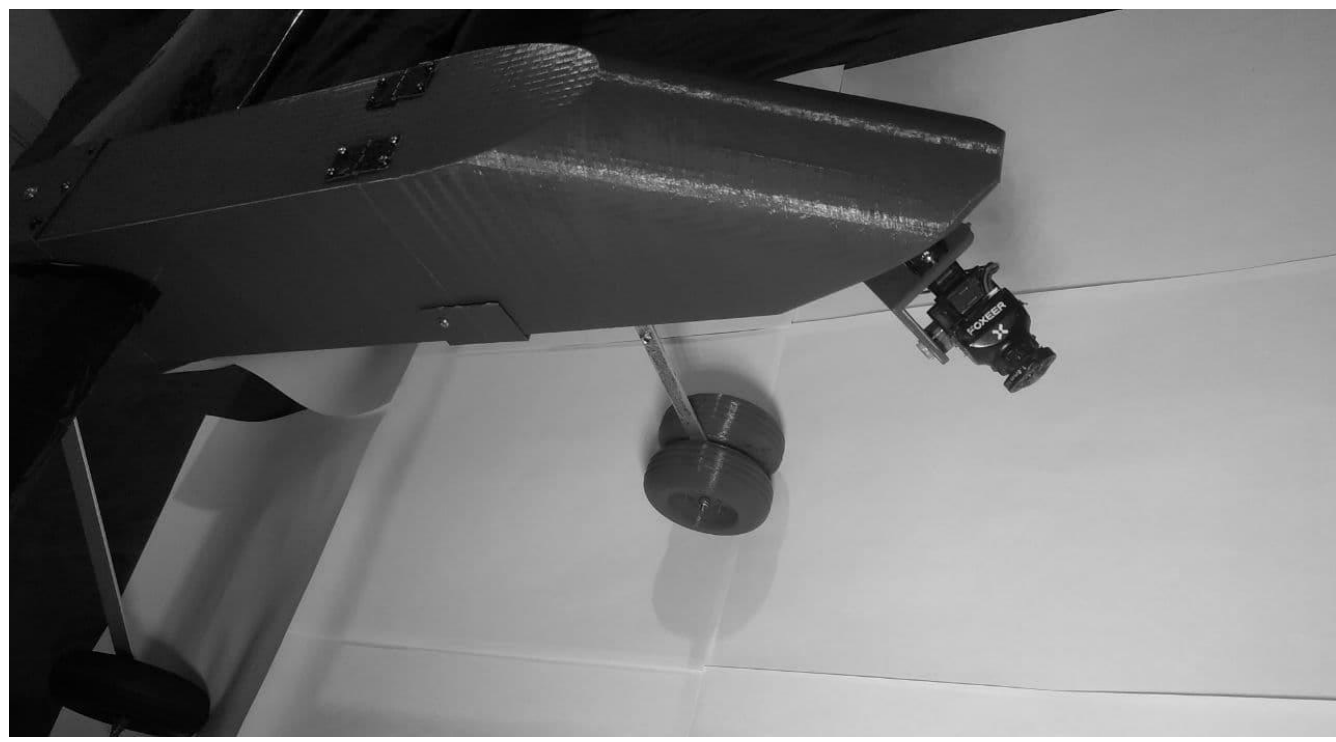

Рис.8 Удосконалення конструкції шасі після тестів

У розширеному режимі маємо такі налаштування швидкості: Travel Speed $150 \mathrm{~mm} / \mathrm{c}$; Bottom Layer Speed 25 мм/c; Infill Speed $60 \mathrm{~mm} / \mathrm{c}$; Top/Bottom Speed 40 mm/c; Outer Shell Speed 40 mm/c; Inner Shell Speed 60 mm/c.

\section{Отримані характеристики БПЛА}

БПЛА відповідає таким основним характеристикам: швидкість горизонтального польоту (V) - 15 м/c; розмах крила (L) - 2,2 м, час польоту (T) - 1 год. Старт виконується кидком з руки, а посадка - на ґрунт на шасі. У табл. 2 представлений ряд вихідних даних, прийнятих незмінними.

Таблиця 2

\section{Вихідні дані БПЛА}

\begin{tabular}{|c|c|}
\hline Параметри & Числові значення \\
\hline Температура повітря, ${ }^{\circ} \mathrm{C}$ & $-12,0$ \\
\hline Швидкість польоту, м/с & 15 \\
\hline Швидкопідйомність, м/с & 5,5 \\
\hline Розмах крила, м & 2,2 \\
\hline Час польоту, год & 1 \\
\hline Кут поперечного V-крила & $+6^{\circ}$ \\
\hline Маса корисного навантаження, кг & 0,4 \\
\hline Максимальний кут відхилення закрилків & $30,0^{\circ}$ \\
\hline Питома енергоємність акумулятора, Вт*год/кг & 300 \\
\hline Максимальна напруга на акумуляторі, В & 12,6 \\
\hline Регулятор струму, кг & 0,060 \\
\hline Питома маса електродвигуна дв, кг/кВт & 0,40 \\
\hline Кількість лопатей повітряного гвинта & 2 \\
\hline Стартове значення злітної маси нульового наближення, кг & 1,5 \\
\hline Маса двигуна, кг & 0,120 \\
\hline Сервопривід, кг & 0,010 \\
\hline Приймач радіосигналу, кг & 0,013 \\
\hline
\end{tabular}


Характеристики навчального БПЛА, наведено в табл. 3.

Таблиця 3

Отримані показники БПЛА

\begin{tabular}{|l|c|}
\hline \multicolumn{1}{|c|}{ Параметри } & Числові показники \\
\hline Питоме навантаження на крило, кг/м & 3,3 \\
\hline Подовження крила & 6 \\
\hline Звуження крила & 1 \\
\hline Розмах крила, м & 2,2 \\
\hline Середня хорда крила, м & 0,15 \\
\hline Площа крила, м² & 0,3 \\
\hline Площа міделевого перерізу фюзеляжу, м ${ }^{2}$ & 0,005 \\
\hline Злітна маса, кг & 2,5 \\
\hline Відносна площа стабілізатора & 0,2 \\
\hline Довжина літака, м & 0,98 \\
\hline Висота літака (з шасі), м & 0,53 \\
\hline Швидкість польоту, км/год & 54 \\
\hline Потужність двигуна, Вт & 600 \\
\hline Діаметр повітряного гвинта, м & 0,27 \\
\hline Маса акумулятора, кг & 0,8 \\
\hline
\end{tabular}

На основі отриманих даних розроблено тривимірну геометричну модель (рис. 9) та побудовано літаючий зразок навчального БПЛА, а також виконано серію випробувальних польотів на ручному дистанційному керуванні.

Двигун такого БПЛА є безколекторним і працює зі швидкістю 800 оборотів за хвилину на одиницю напруги у вольтах з максимальною тягою 2 кг. Регулятор контролює роботу двигуна і розрахований на струм до $50 \mathrm{~A}$. Акумулятор LiPol 4S з ємністю 8000 мАг забезпечує до 1 години польоту. Польотний контролер використовує різні датчики, але в обов'язковому порядку, мають бути встановлені триосьовий гіроскоп і акселерометр для вимірювання кутової швидкості і прискорення а також датчики GPS, OSD, Telemetry 915 Гц, Reciver 2,4 Гц, UBEC, FPV 5,8 Гц.

Апаратура керування має бути 16-канальною. Це потрібно, щоб керувати параметрами газу, крену, тангажу, камерою в двох площинах, освітленням БАНО, рисканням та режимом.

Для виконання цього проекту були вибрані такі комплектуючі: регулятор Simonk 50 A 4 S, двигун Sk3-4240-740kv, польотний контролер АРМ 2.8, гвинт carbon 13x8, GPS Radiolink, OSD APM, Telemetry 3DR $915 \mathrm{Ghz}$, Receiver 2.4Ghz radiomaster ppm, UBEC 5V/5A, FPV 5.8Ghz $2000 \mathrm{~mW}$, Foxer 1/3 900TVL, Radiomaster TX16s, Eachine EV800D, Multistar 4s 8000mAh, Imax b6 original 50W.

Для зручності експлуатації і транспортування в БПЛА передбачено можливість відстикування крила від фюзеляжу а також складний фююзеляж рис. 10. Відстиковане крило відкриє доступ у відсік фюзеляжу, де розташовують акумулятор, приймач радіосигналу керування, регулятор потужності двигуна, кермовий привід керма висоти. Перший відсік фююеляжу, відокремлений від верхньої горизонтальної перегородки, призначено для розміщення контрольновимірювальної апаратури та модуля автопілота. Крило розбірне, однолонжеронне, у внутрішньому об'ємі якого розташовано рульові приводи елеронівзакрилків. 


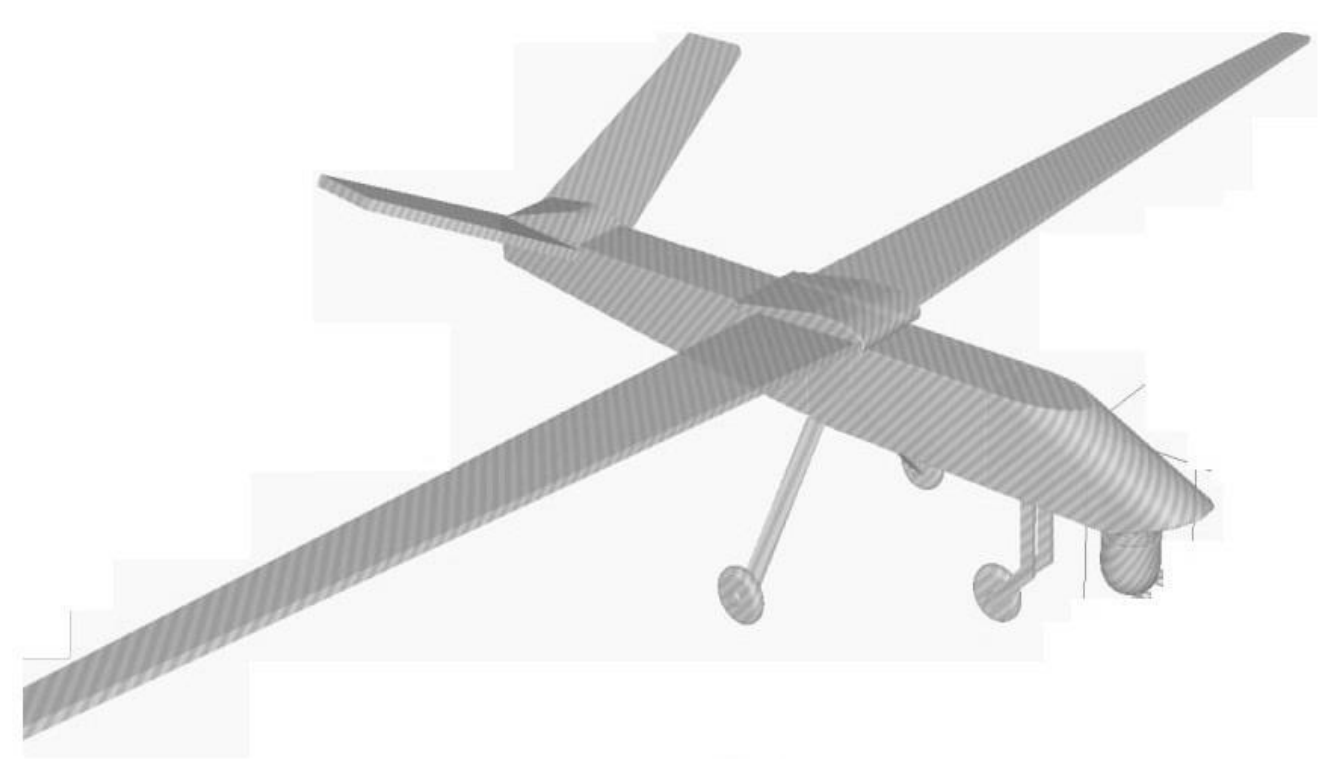

Рис. 9. Тривимірна геометрична модель БПЛА

\section{Висновки}

На основі модифрікованого рівняння існування літака розроблено методику вибору основних параметрів малорозмірних низько швидкісних навчальних БПЛА на початкових стадіях проектування. Паралельне врахування вагового та енергетичного балансів літального апарату за допомогою рівняння існування літака дозволяє отримувати результат за короткий проміжок часу. Використання запропонованої методики продемонстровано на прикладі розробки БПЛА для набуття початкових навичок керування в ручному та автоматичному режимах. 3 урахуванням отриманих розрахункових даних побудовано льотний зразок та проведено серію випробувальних польотів. Льотні випробування підтвердили якісні характеристики ЛА, закладені при проектуванні: апарат має хорошу стійкість і керованість у всіх каналах керування на малих швидкостях польоту, а також достатню енергоозброєність для виконання інтенсивного набору висоти та розвороту малого радіусу без ковзання. Механізація крила дозволяє виконувати м'яку посадку на пружне шасі з малою швидкістю на майданчики обмежених розмірів в умовах міста.

Як наступний етап розвитку запропонованої концепції комплексної підготовки пілотів і операторів БПЛА планується удосконалити БПЛА для використання в різних погодних умовах.

Такий підхід до створення БПЛА при застосуванні можливих технічних доробок дозволяє додатково реалізувати концепцію не лише навчального, а й навчально-дослідного БПЛА для проведення досліджень з оцінювання ефекту впровадження окремих інновацій у конструкцію та обладнання літальних апаратів. Наприклад, такий БПЛА може бути літаючою платформою для дослідження нових аеродинамічних схем, вивчання перспектив застосування адаптивного крила, розподіленої силової установки, енергетичної механізації крила.

\section{Список літератури}

1. Загальні види та характеристики безпілотних літальних апаратів: довід. 
посібник / Гребеніков А. Г.,. Мялиця А. К,. Парфенюк В. В та ін. - Харків : Нац. аерокосм. ун-т "Харк. авіац. ун-т", 2008 - 377 с.

2. Лук'янов, О. Є. Методологічне забезпечення підготовки проектантів та операторів безпілотних літальних апаратів. / О. Є. Лук'янов, Д. В. Золотов // Вісник Самарського університету.

3. Аерокосмічна техніка, технології та машинобудування. 2021. Т. 20 № 1. C. 14-28. DOI: 10.18287/2541-7533-2021-20-1-14-28. Електронний ресурс. Режим доступу: https: //www.militaryfactory.com

4. Гребеніков, А. Г. Аналіз статистичних даних безпілотних літальних апаратів вертолітного типу / А. Г. Гребеніков, Т. Н. Середа, Т. П. Цепляєва, Є. Ю. Шевченко, А. А. Юхно // Відкриті інформаційні та комп'ютерні технології: зб. наук. пр. Нац. аерокосм. ун-та им. М.Є. Жуковського «XАІ». - Вип. 80 - Харків, 2018. - С. $5-22$.

5. Цепляєва, Т. П. Аналіз сучасного стану розвитку висотних безпілотних літальних апаратів / Т. П. Цепляєва, А. Ю. Мигунов // Відкриті інформаційні та комп'ютерні технології: зб. наук. пр. Нац. аерокосм. Ун-та им. М.Є. Жуковського «XAl». - Вип. 83 - Харків, 2019. - С. 28 - 41.

\section{References}

1.Zagal'ni vy'dy' ta xaraktery'sty`ky' bezpilotny'x lital'ny'x aparativ: dovid. posibny`k [General Characteristics of Unmanned Aerial Vehicles]/ Grebenikov A. G.,. Myaly`cya A. K,. Parfenyuk V. V ta in. - Xarkiv : Nacz. aerokosm. un-t "Xark. aviacz. un-t", $2008-377$ p.

2. Luk'yanov, O. Ye. Metodologichne zabezpechennya pidgotovky proektantiv ta operatoriv bezpilotny $x$ lital'ny' $x$ aparativ [Methodological support for the training of designers and operators of unmanned aerial vehicles]. / O. Ye. Luk'yanov, D. V. Zolotov // Vis-ny`k Samars`kogo universy`tetu.

3. Aerokosmichna texnika, texnologiyi ta mashy`nobuduvannya [Aerospace engineering, technology and mechanical engineering]. 2021. V. 20. No. 1. P. 14-28. DOI: 10.18287/2541-7533-2021-20-1-14-28. Elektronny j resurs. Rezhy'm dostupu: https: //www.militaryfactory.com

4. Grebenikov, A. G. Analiz staty`sty`chny`x dany`x bezpilotny`x lital'ny`x aparativ vertolitnogo ty 'pu [Analysis of statistical data of helicopter unmanned aerial vehicles] / A. G. Grebenikov, T. N. Sereda, T. P. Ceplyayeva, Ye. Yu. Shevchenko, A. A. Yuxno // Vidkry`ti informacijni ta komp'yuterni texnologiyi: zb. nauk. pr. Nacz. aerokosm. un-ta y`m. M.Ye. Zhukovs`kogo «XAI». - Issue 80 - Xarkiv, 2018. - P. 5 22.

5. Ceplyayeva, T. P. Analiz suchasnogo stanu rozvy`tku vy`sotny`x bezpilotny'x lital'ny'x aparativ [Analysis of the current state of development of highaltitude unmanned aerial vehicles]/ T. P. Ceplyayeva, A. Yu. My'gunov // Vidkry`ti informacijni ta komp'yuterni texnologiyi: zb. nauk. pr. Nacz. aerokosm. Un-ta y’m. M.Ye. Zhukovs`kogo «XAl». - Vy`p. 83 - Xarkiv, 2019. - S. 28 - 41.

\section{A Method of Creating an Airplane-type Training UAV Using 3D-printing}

The concept of specialized training unmanned aerial vehicle (UAV) of airplane type for operators of unmanned aerial vehicles is proposed. Training opportunities in various areas of operator training are highlighted. A method of manufacturing an 
airplane-type training UAV taking into account aerodynamic and weight characteristics has been developed. The developed technique is based on the production of aircraft parts using a 3D printer, which is modified to meet the requirements of small airplane-type aircraft. This technique also includes the process of selecting the most advantageous combination of materials to create a small aircraft. Tables with initial data of existing UAVs are given.

The flight characteristics, aerodynamic schemes and types of engine that are most rationally suitable for unmanned aerial vehicles in accordance with this class are proposed. Based on these data, a prototype model was built, the method of UAV design was adopted, taking into account the choice of parameters of the power plant. A demonstration example of the choice of the main parameters of a training UAV taking into account the UAV under specific requirements is given. The obtained main technical characteristics of the UAV are presented. Based on the calculated data, a three-dimensional geometric model of the UAV was developed and a flight sample was made. A series of test flights of the flight model was conducted, tested in difficult weather conditions, when the wind force is about $12 \mathrm{~m} / \mathrm{s}$. The ways of using the described method of development of training and research UAVs are considered, as well as many other factors that affect 3D printing without detecting defects and problems.

Key words: UAV training; plane; take-off mass; choice of parameters; designing; aerodynamics; 3D printing; summer model; trial.

\section{Відомості про авторів:}

Олександр Григорович Гребеніков - доктор технічних наук, професор каф.103 «Проектування літаків і вертольотів» Національного аерокосмічного університету ім. М. Є. Жуковського «Харківський авіаційний інститут», Україна, e-mail: o.grebenikov@khai.edu

Калоша Олексій Сергійович - аспірант каф.103 «Проектування літаків і вертольотів» Національного аерокосмічного університету ім. М. Є. Жуковського «Харківський авіаційний інститут», Україна, e-mail: o.kalosha@khai.edu.

\section{About the Authors:}

Oleksandr Grebenikov - Doctor of Technical Sciences, Professor of Department 103 "Design of Airplanes and Helicopters" of the National Aerospace University "Kharkiv Aviation Institute", Ukraine, e-mail: o.grebenikov@khai.edu

Oleksii Kalosha - post-graduate student of department 103 "Design of airplanes and helicopters" of the National Aerospace University "Kharkiv Aviation Institute", Ukraine, e-mail: o.kalosha@khai.edu. 